\title{
INEL/CON-97-00011 \\ CONF-970335-52 INEL/CON-97-00011 \\ Results after Ten Years of Field Testing Low-level Radioactive Waste Forms Using Lysimeters
}

\author{
John W. McConnell, Jr., Robert D. Rogers, Julie D. Jastrow, ${ }^{a}$ \\ William E. Sanford, ${ }^{b}$ Steven R. Cline, ${ }^{b}$ Terry M. Sullivan, ${ }^{c}$ and Mark Fuhrmann ${ }^{c}$ \\ Idaho National Engineering Laboratory \\ P.O. Box 1625, Idaho Falls, Idaho 83415
}

\section{ABSTRACT}

The Field Lysimeter Investigations: Low-Level Waste Data Base Development Program is obtaining information on the performance of radioactive waste forms. These experiments were recently shut down and have been examined in accordance with a detailed waste form and soil sampling plan. Ion-exchange resins from a commercial nuclear power station were solidified into waste forms using portland cement and vinyl ester-styrene. These waste forms were tested to (a) obtain information on performance of waste forms in typical disposal environments, (b) compare field results with bench leach studies, (c) develop a low-level waste data base for use in performance assessment source term calculations, and (d) apply the DUST computer code to compare predicted cumulative release to actual field data. The program, funded by the Nuclear Regulatory Commission (NRC), includes observed radionuclide releases from waste forms in field lysimeters. The purpose of this paper is to present the experimental results of two lysimeter arrays after 10 years of operation, and to compare those results to bench test results and to DUST code predictions of releases using recently developed partition coefficients. This paper discusses soil and waste form sampling in which vertical cores were removed from the lysimeter soil columns for laboratory characterization. Soils will be analyzed for radionuclide movement. Further analysis of soil cores taken to define the observed upward migration of radionuclides in one lysimeter is also presented.

\section{INTRODUCTION}

This paper presents 10 years of experimental results of two instrumented field lysimeter arrays. While results of this program have been presented at previous WM meetings, this paper will give an update of the study, which will include discussion of the results of the examination of the soils and waste forms of the two lysimeter arrays after experiment shutdown and exhumation. During the examination, the waste forms are being characterized, after removal from the lysimeter, and these results compared to the original characterizations, thus providing the basis for a material balance of the radionuclides present. Vertical soil cores were taken from the soil

a. Argonne National Laboratory, Argonne, IL 60439.

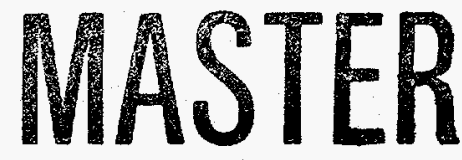

b. Oak Ridge National Laboratory, Oak Ridge, TN 37831.

c. Brookhaven National Laboratory, Upton, NY 11973. 
columns and are being analyzed by radio chemistry to determine movement of radionuclides after release from the waste forms. A comparison is made of the DUST code predicted releases to releases previously determined and reported from the lysimeter leachate analyses. That comparison uses new distribution coefficients $\left(\mathrm{K}_{\mathrm{d}}\right)$ recently obtained from laboratory analysis of the lysimeter soils and sand.

Concern over the practices associated with the disposal of low-level radioactive waste (LLW) has resulted in a very real need to obtain accurate data on the long-term field performance of these wastes. The U.S. Nuclear Regulatory Commission (NRC) has enacted regulations that link LLW acceptance criteria to the long-term satisfactory performance of the waste. Under Code of Federal Regulations (CFR) 10, Part 61, "Licensing Requirements for Land Disposal of Radioactive Wastes" (1), commercially generated LLW is classified as Class A, B, C, or Greater Than Class C. Wastes classified as either Class B or Class $C$ must be stabilized for a minimum of 300 years.

To verify the 300 -year stability of waste forms, the NRC originally specified the use of short-term standardized tests with the intention that such tests would provide information relevant to near-surface disposal performance objectives. Those tests, which were initially published in the NRC Branch "Technical Position on Waste Form" (2), and have been revised in Revision 1 of the Technical Position (3), continue to undergo critical reviews to determine their applicability to the 300 -year stability requirements.

A central requirement for disposing LLW is the need for a detailed understanding of the waste form behavior. That is necessary because the radionuclide source is the driving force behind the site performance. A major requirement in any site licensing is the site performance assessment, which is used to evaluate whether or not a proposed disposal site will meet performance objectives. Assumptions regarding the performance of the buried waste form have a direct bearing on the outcome of the performance assessment.

The objective of the Field Lysimeter Investigations: Low-Level Waste Data Base Development Program is to compare the results of short-term laboratory leach testing, performed earlier by the INEL, with actual leaching in the field. Also, the waste forms are being field-tested to develop a low-level radioactive waste leach rate data base. This program, funded by the NRC, has been operating lysimeters for over 10 years to obtain information on the performance of radioactive waste forms in a disposal environment and to investigate waste form stability per requirements of $10 \mathrm{CFR} 61$. The experiment measures the releases of radionuclides and chemical species from the waste forms and the subsequent transport through soil columns to sampling locations within the lysimeters. This study was developed to field test waste forms composed of solidified ion-exchange resin materials from EPICOR-II ${ }^{\mathrm{a}}$ prefilters used in the cleanup of Unit 2 of the Three Mile Island Nuclear Power Station (4). Wastes used in the study are significant because they have high loadings of radionuclides and are comprised on ion-exchange media of the type used by the nuclear industry.

a. References herein to any specific commercial product, process, or service by trade name, trademark, manufacturer, or otherwise, does not necessarily constitute or imply its endorsement, recommendations, or favoring by the United States Government or any agency thereof. 


\section{DISClamier}

Portions of this document may be illegible in electronic image products. Images are produced from the best available original document. 


\section{DISCLAIMER}

This report was prepared as an account of work sponsored by an agency of the United States Government. Neither the United States Government nor any agency thereof, nor any of their employees, makes any warranty, express or implied, or assumes any legal liability or responsibility for the accuracy, completeness, or usefulness of any information, apparatus, product, or process disclosed, or represents that its use would not infringe privately owned rights. Reference herein to any specific commercial product, process, or service by trade name, trademark, manufacturer, or otherwise does not necessarily constitute or imply its endorsement, recommendation, or favoring by the United States Government or any agency thereof. The views and opinions of authors expressed herein do not necessarily state or reflect those of the United States Government or any agency thereof. 



\section{EXPERIMENT DESCRIPTION}

Wastes used in the experiment include a mixture of highly loaded, nuclear-grade, synthetic, organic ion-exchange resins from EPICOR-II prefilter PF-7 and a mixture of organic-exchange resins and an inorganic zeolite from prefilter PF-24. Solidification agents employed to produce the $4.8 \times 7.6-\mathrm{cm}$ cylindrical waste forms used in the study were portland type I-II cement and DOW vinyl ester-styrene (VES). Seven of the waste forms were stacked end-to-end and inserted into each lysimeter to provide a 1-L volume. The PF-7 waste contained $89 \%$ of the radionuclide activity as Cs-137, while PF-24 contained 94\% Cs-137. The PF-7 waste also contained 5\% Sr-90, and PF-24 contained 1\% Sr-90. There were also measurable amounts of Cs-134, Co-60, and $\mathrm{Sb}-125$ found in those wastes. Details on waste form descriptions, formulations, and technical position testing are given in References (4) and (5). A listing of lysimeter waste form and fill material types are given in Reference (6).

Ten lysimeters were used in this study: five at Oak Ridge National Laboratory (ORNL) in Tennessee and five at Argonne National Laboratory-East (ANL-E) in Illinois. The lysimeters were designed to be self-contained units that will be disposed at the termination of the study. Each lysimeter is a $0.91 \times 3.12-\mathrm{m}$ right-circular cylinder divided into an upper compartment that contains fill material, waste forms, and instrumentation, and a lower compartment for collecting leachate (Fig. 1). Four lysimeters at each site are filled with soil; a fifth, used as a control, is filled with inert silica oxide sand. The lysimeters at ANL-E contain soil indigenous to the site, while the ORNL lysimeters contain soil taken from Savannah River Laboratory in South Carolina. The soil columns are $2.21 \mathrm{~m}$ deep.

Instrumentation in each lysimeter includes moisture cup soil-water samplers and soil moisture/ temperature probes. The probes are connected to an onsite data acquisition system (DAS), which also collects data from a field meteorological station located at each site. Porous cup soil-water samplers and the leachate collection compartment comprise the water sampling components of each lysimeter (Fig. 1). Incoming precipitation moves downward through the soil column to the waste form, then on to cups 3 and 1 , and finally to the leachate collector at the bottom. Moisture entering the soil at the edge of the lysimeter encounters cups 5, 4, or 2 as it moves downward. Samples of moisture are withdrawn from the cups and the collector. Radial movement of waste form releases are detected in cups 5, 4, and 2, while vertical release is observed by cups 3 and 1 . Lysimeter design, installation, instrumentation, operation, and data acquisition are explained in Reference (6).

Monitoring of the lysimeters at ANL-E and ORNL began with the collection of liquid samples in September 1985 ( 3 months from the time of placement) and continued through shutdown in October 1995 with sample collection on approximately a quarterly basis. Samples of liquids were taken from locations near the waste forms and from the leachate collectors to track the migration of radionuclides, primarily Cs-137. The water samples were analyzed for Sr-90 and gammaproducing nuclides. Each month, data stored on a cassette tape in the DAS were retrieved and translated into an IBM PC-compatible disk file. Soil moisture and temperature at three elevations in each lysimeter, along with a complete weather history, were recorded on a continuing basis by the DAS. Testing results are presented in Reference (7) as well as in this paper. 


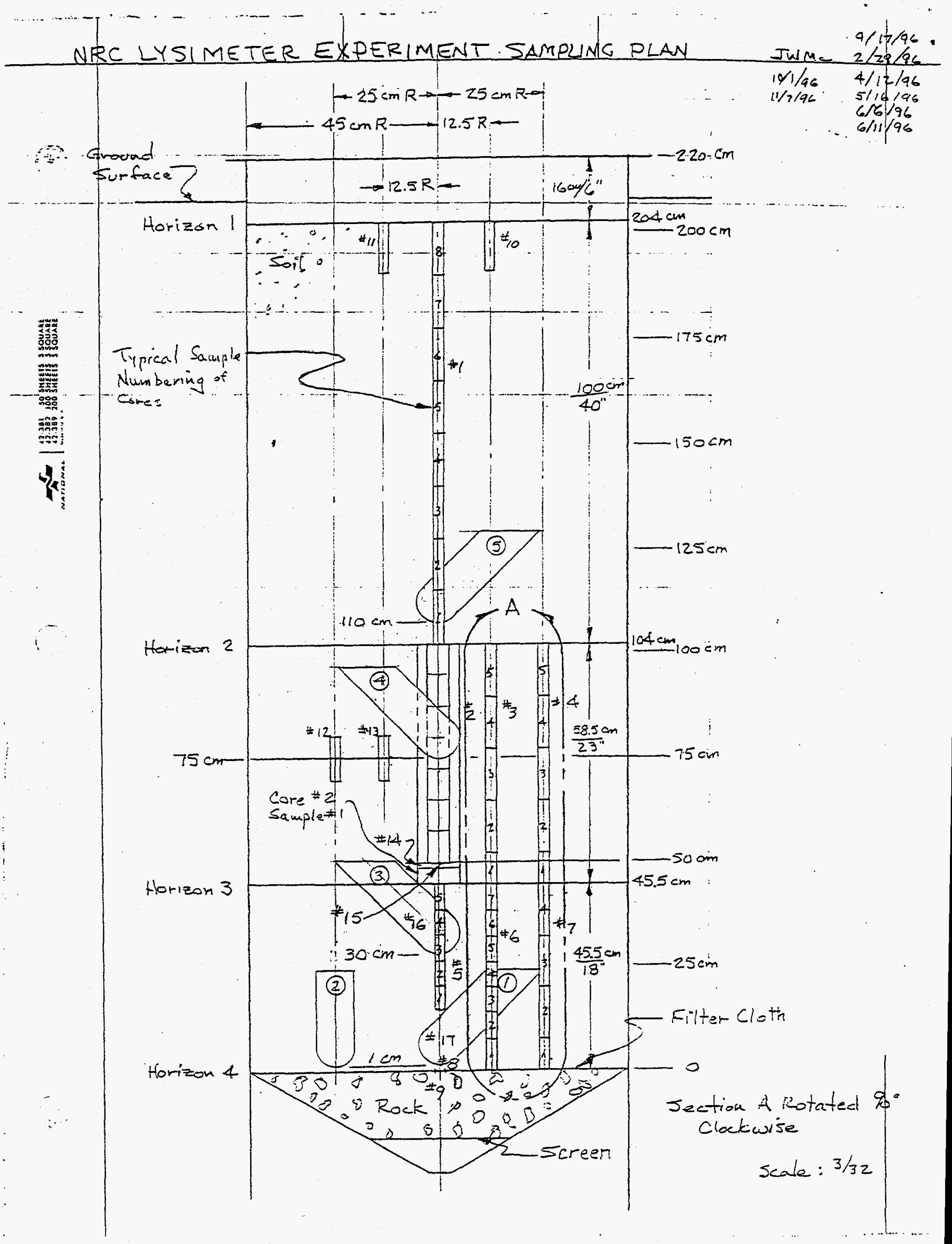

Fig. 1. Schematic showing the lysimeter vessel and experiment sampling. 


\section{RESULTS AND DISCUSSION}

\section{Weather and Soil Data}

Precipitation, air temperature, wind speed, and relative humidity were recorded continuously by the ANL-E and ORNL DAS during the experiment. The cumulative volume of leachate from the lysimeters since the initiation of field work, and examples of the lysimeter soil temperature and moisture data obtained at ANL-E and ORNL can be found in Reference (7). Data recorded in FY-95 indicate that the lysimeter soil columns at both sites have remained moist during the last reporting period.

\section{Radionuclide Data from Leachates}

Figs. 2 and 3 show examples of data on the cumulative amounts of nuclides as determined in water samples obtained from ANL-E and ORNL leachate collectors, respectively. Other data show that not all nuclides consistently appeared in the water obtained from the moisture cups or the leachate collectors. The nuclide that appeared with the most regularity at both sites was Sr-90. Table I contains a comparison of the percent of inventory release of Sr-90 and Cs-137 found in the moisture cups and leachate water.

At both ORNL and ANL-E, recovery of Sr-90 in number 3 cups $(22.4 \mathrm{~cm}$ below the waste form in the soil column) and the leachate collectors indicates a varied waste form performance (Table I). Recovery of Sr-90 in the ORNL cups is comparable for those lysimeters containing the cement waste forms and one of the two containing VES waste forms. However, the cups at ANL-E are recovering much more Sr-90 from the VES waste forms compared to the cement waste forms. These data indicate that releases from the cement waste forms are generally less than from VES waste forms.

Movement of the nuclide into the leachate collectors of the inert, sand-filled control lysimeter 5 is much greater than that of the other lysimeters and thus provides evidence of the moderating effect of soil (versus the inert sand) in those lysimeters. During the past several years, leachate collector water from the control lysimeters at each site has contained amounts of Sr-90 at least an order of magnitude larger than releases from the soil lysimeters (Figs. 2 and 3) (7). The total Sr-90 being measured in the leachate collector waters remains somewhat inconsistent between the two sites (Table I). It is suspected that this represents a difference in how the environment at the two sites affects the movement of Sr-90 being released from the waste forms. The higher release of $\mathrm{Sr}-90$ from the ORNL control lysimeter waste form reflects the nearly $50 \%$ higher rainfall experienced at that site over that seen at ANL-E.

Gamma-producing nuclides continue to occur with regularity at both sites (Table I). However, only waste forms at ORNL are releasing detectable amounts of Cs-137 to the leachate waters (Table I). It is not possible to make a comparison of Cs-137 releases from cement and VES waste forms at this time due to the small releases. 


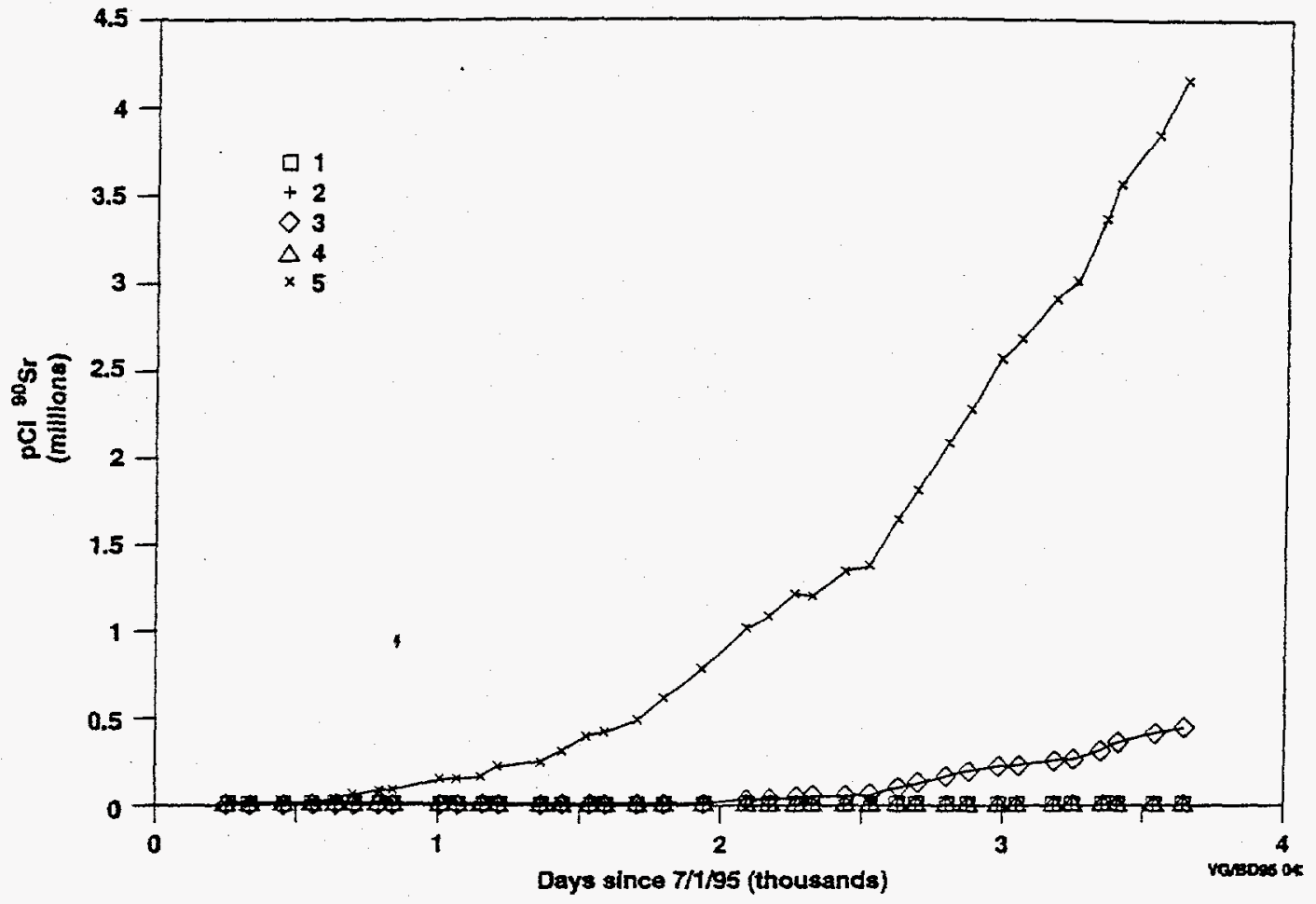

Fig. 1. ANL-E cumulative Sr-90 collected in lysimeter leachate collectors.

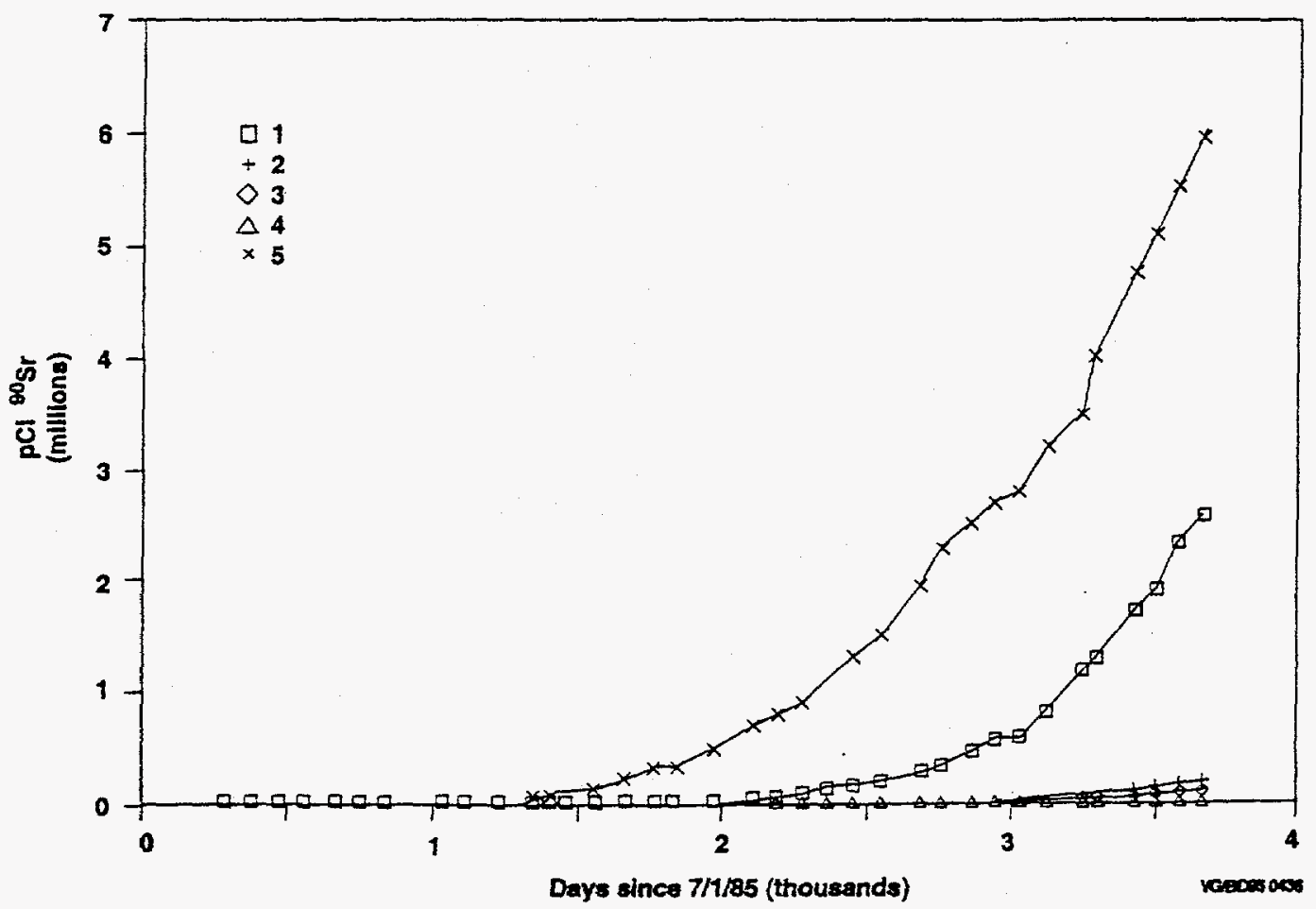

Fig. 2. ORNL cumulative Sr-90 collected in lysimeter leachate collectors. 
Table I. Percent release of Sr-90 and Cs-137 per lysimeter in moisture cups and leachate water through July 1995 (7).

\begin{tabular}{|c|c|c|c|c|c|c|c|c|c|}
\hline \multirow{3}{*}{$\begin{array}{l}\text { Lysimeter } \\
\text { Number }\end{array}$} & \multirow{3}{*}{$\begin{array}{l}\text { Solidifi- } \\
\text { cation } \\
\text { Agent }\end{array}$} & \multicolumn{4}{|c|}{$\begin{array}{l}\text { Percent Total Inventory } \\
\text { Sr-90 }\end{array}$} & \multicolumn{4}{|c|}{$\begin{array}{l}\text { Percent Total Inventory } \\
\text { Cs-137 }\end{array}$} \\
\hline & & \multicolumn{2}{|c|}{$\begin{array}{l}\text { Moisture } \\
\text { Cups }\end{array}$} & \multicolumn{2}{|c|}{$\begin{array}{l}\text { Leachate } \\
\text { Water }\end{array}$} & \multicolumn{2}{|c|}{$\begin{array}{l}\text { Moisture } \\
\text { Cups }\end{array}$} & \multicolumn{2}{|c|}{$\begin{array}{l}\text { Leachate } \\
\text { Water }\end{array}$} \\
\hline & & ANL-E & ORNL & ANL-E & ORNL & ANL-E & ORNL & ANL-E & ORNL \\
\hline 1 & Cement & $1.4 \mathrm{E}-4$ & $9.7 E-4$ & $0.4 \mathrm{E}-4$ & $0.4 \mathrm{E}-4$ & $-{ }^{a}$ & - & - & $1.7 \mathrm{E}-6$ \\
\hline 2 & Cement & $4.4 \mathrm{E}-4$ & $7.8 \mathrm{E}-4$ & $0.7 \mathrm{E}-4$ & $0.7 \mathrm{E}-4$ & $0.2 \mathrm{E}-6$ & - & - & $0.1 \mathrm{E}-6$ \\
\hline 3 & VES & $69.4 \mathrm{E}-4$ & $13.0 \mathrm{E}-4$ & $16.1 \mathrm{E}-4$ & $16.1 \mathrm{E}-4$ & - & - & - & $1.4 \mathrm{E}-6$ \\
\hline 4 & VES & $14.7 \mathrm{E}-4$ &, $3.3 \mathrm{E}-4$ & $2.2 \mathrm{E}-4$ & $2.2 \mathrm{E}-4$ & - & - & - & $0.4 E-6$ \\
\hline 5 & Cement & 2.7E-4 & $8.8 \mathrm{E}-4$ & $225.0 \mathrm{E}-4$ & $1,812.0 \mathrm{E}-4$ & $71.9 \mathrm{E}-6$ & $1.3 \mathrm{E}-6$ & - & $434.0 \mathrm{E}-6$ \\
\hline
\end{tabular}

Table II is a comparison of cumulative fractional releases from field testing EPICOR-II waste forms in lysimeters to releases from bench-leach-testing similar waste forms as reported in References (5) and (8). Releases observed in the lysimeter are at least two orders of magnitude less for Sr-90 and at least five orders of magnitude less for Cs-137 in soil. Release of Sr-90 in the sand-filled lysimeter is only one or two orders of magnitude less than bench test results.

\section{Lysimeter Waste Form and Soil Core Sampling}

The primary objective of the waste form and soil sampling was to obtain the entire waste form from each of the five lysimeters at each site in a cylindrical core, which could be transported to the INEL for detailed examination. Secondary objectives were to extract soil cores, soil microbial samples, selected moisture cups, filter fabric samples, and filter support stone samples. Seven soil cores were to be taken per lysimeter, one for the waste form and six for soils. Four soil grab samples, one filter cloth cut sample, and one filter support rock grab sample per lysimeter are planned. Moisture cup numbers 1 and 3 from each lysimeter also were to be collected.

A diagram of the sample locations and sizes is shown in Fig. 1, and Table III lists the cores and samples. The waste form cores (number 2) are $7.5 \mathrm{~cm}$ in diameter and $58.5 \mathrm{~cm}$ long and extend from horizon 2 to 3 . That length contains all seven waste form samples. The soil cores and microbial soil samples are $3.3 \mathrm{~cm}$ in diameter and are various lengths. All were taken with coring tools made up of $25-\mathrm{cm}$ long segments. Cores number 1 were taken with a $75-\mathrm{cm}$ top segment, then a $25-\mathrm{cm}$ long bottom segment. All other cores were taken at full depth. The microbial soil samples were also taken with the $3.3-\mathrm{cm}$ diameter tool using one segment. All cores were contained in plastic, cylindrical-core tool liners that were closed with plastic caps on the ends. 
Table II. Cumulative fractional releases from lysimeter field testing compared to those from bench leach testing $(5,7,8)$.

\begin{tabular}{|c|c|c|c|c|c|c|c|}
\hline \multirow[b]{3}{*}{ Test Type } & \multirow{3}{*}{$\begin{array}{l}\text { Prefilter } \\
\text { Number }\end{array}$} & \multirow{3}{*}{$\begin{array}{l}\text { Solidifi- } \\
\text { cation } \\
\text { Agent }\end{array}$} & \multirow[b]{3}{*}{ Radionuclide } & \multicolumn{4}{|c|}{ Cumulative Fractional Release } \\
\hline & & & & \multirow{2}{*}{$\begin{array}{c}\text { Deminer- } \\
\text { alized } \\
\text { Water }\end{array}$} & \multirow[b]{2}{*}{ Seawater } & \multicolumn{2}{|c|}{$\begin{array}{l}\text { Leachate } \\
\text { Collectors }\end{array}$} \\
\hline & & & & & & Soil & Sand \\
\hline Bench & 7 & Cement $^{\mathrm{a}}$ & Sr -90 & $7.8 \mathrm{E}-2$ & - & - & - \\
\hline Bench & 7 & Cement $^{a}$ & Cs-137 & $9.0 \mathrm{E}-2$ & - & - & - \\
\hline Bench & 7 & $\mathrm{VES}^{\mathrm{a}}$ & Sr -90 & 4.5E-2 & - & - & - \\
\hline Bench & 7 & $V_{E S}^{a}$ & Cs -137 & $4.0 \mathrm{E}-2$ & - & - & - \\
\hline Bench & 7 & Cement & Cs -137 & $4.8 \mathrm{E}-2$ & $9.0 \mathrm{E}-2$ & - & - \\
\hline Bench & 24 & Cemęnt & Cs -137 & $2.3 \mathrm{E}-2$ & $2.6 \mathrm{E}-2$ & - & - \\
\hline Bench & 7 & VES & Cs -137 & $2.1 \mathrm{E}-3$ & $6.4 \mathrm{E}-2$ & - & - \\
\hline Bench & 24 & VES & Cs -137 & $3.0 \mathrm{E}-4$ & $1.3 \mathrm{E}-2$ & - & - \\
\hline Field, ANL-E & 7 & Cement & Sr-90 & - & - & $3.7 \mathrm{E}-7$ & $2.3 \mathrm{E}-4$ \\
\hline Field, ANL-E & 24 & Cement & Sr -90 & - & - & $7.0 \mathrm{E}-7$ & - \\
\hline Field, ANL-E & 7 & VES & Sr-90 & - & - & $1.6 \mathrm{E}-5$ & - \\
\hline Field, ANL-E & 24 & VES & Sr-90 & - & - & $2.2 \mathrm{E}-6$ & - \\
\hline Field, ORNL & 7 & Cement & Sr-90 & - & - & $1.4 \mathrm{E}-4$ & - \\
\hline Field, ORNL & 24 & Cement & Sr -90 & - & - & $4.6 \mathrm{E}-5$ & $1.8 \mathrm{E}-3$ \\
\hline Field, ORNL & 7 & VES & $\mathrm{Sr}-90$ & - & - & $4.5 \mathrm{E}-6$ & - \\
\hline Field, ORNL & 24 & VES & Sr-90 & - & - & $4.8 \mathrm{E}-6$ & - \\
\hline Field, ORNL & 7 & Cement & Cs- 137 & - & - & $1.7 \mathrm{E}-8$ & - \\
\hline Field, ORNL & 24 & Cement & Cs- 137 & - & - & $1.4 \mathrm{E}-9$ & 4.3E-6 \\
\hline Field, ORNL & 7 & VES & Cs- 137 & - & - & $1.4 \mathrm{E}-8$ & - \\
\hline Field, ORNL & 24 & VES & Cs-137 & - & - & $3.8 \mathrm{E}-9$ & - \\
\hline
\end{tabular}

a. Waste form samples were irradiated before test.

Radial and vertical position of the coring tools was controlled during coring operations by use of special guide plates and bushings. The coring tools and tips were specifically designed for this task by Art's Manufacturing and Supply of American Falls, Idaho. The tool driver was a Bosch roto-hammer. The INEL designed the special guide system.

Radiochemical characterization, including full length gamma scanning of each seven-sample waste form, will provide information on the remaining waste form radionuclide inventory, while waste form physical condition will be determined by visual examination, weighing, and compressive testing. Soil cores will be radiochemically analyzed for nuclide content, as will the filter cloth, filter support stone, and moisture cup. These data will then be used to determine radionuclide material balance within each lysimeter, radionuclide pathways through the soil columns, and radionuclide holdup factors of the various components of each lysimeter system. Other soil samples will be examined for microbial activity, which may then be related to waste form physical condition indirectly or more directly by microbial examination of waste form surface scraping samples. 


\section{Upward Migration of Radionuclides at ORNL}

During previous samplings, the presence of both Cs-137 and Sr-90 were discovered at the surface of lysimeter ORNL-5, which is the sand-filled control. Radionuclide activity was first detected in 1991 during a routine gamma survey of the lysimeter's surface. At that time, more activity was found near the center than at the edges. Core samples were obtained from the center of the lysimeter at depths from 0 to $2.5 \mathrm{~cm}$ and from 2.5 to $5 \mathrm{~cm}$ for analysis of cesium and

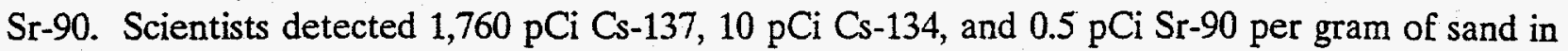
the 0 to $2.5-\mathrm{cm}$ core, and $306 \mathrm{pCi} \mathrm{Cs}-137,3 \mathrm{pCi} \mathrm{Cs}-134$, and $0.1 \mathrm{pCi} \mathrm{Sr}-90$ in the 2.5 to 5 -cm core material. These data showed that more radionuclides were at the surface, suggesting some type of an active deposition mechanism. There remained a question, however, concerning the source of the radionuclides. In August of 1992, samples were again taken from the lysimeter and analyzed for Cs-137 and Cs-134. The results were similar to the previous sampling, with $1,533 \mathrm{pCi} \mathrm{Cs-137}$ and $6 \mathrm{pCi} \mathrm{Cs}-134$ being found per gram in the surface, and $574 \mathrm{pCi} \mathrm{Cs}-137$ and $2.4 \mathrm{pCi} \mathrm{Cs}-134$ per gram in the 2.5 to $5-\mathrm{cm}$ sample. A comparison was made between the ratio of $\mathrm{Cs}-137$ and Cs-134 in the surface material and the ratio in the buried waste form. It was concluded that the contamination of cesium came from the waste form within the lysimeter soil column.

On January 31, 1994, two cores of sand $80 \mathrm{~cm}$ long were collected from lysimeter 5 . One core was taken from the side of the lysimeter near the wall, and the other core was removed from the center of the lysimeter directly above the buried waste form (located approximately $100 \mathrm{~cm}$ below the sand surface). These sand cores were sectioned into 5 -cm segments. Radiocesium and strontium activity were measured for each segment. Results are given in Table III.

Table III. Core samples.

\begin{tabular}{|c|c|c|c|}
\hline & $\begin{array}{c}\text { Number of } \\
\text { Samples/Makeup }\end{array}$ & $\begin{array}{c}\text { Sample Length } \\
(\mathrm{cm})\end{array}$ & Designation \\
\hline 1 & 8 & 12.5 & Radionuclide \\
2 & 1 & 54.5 & Radionuclide \\
3 & 1 & 4.0 & Radionuclide \\
Radionuclide \\
4 & 4 & 12.5 & Radionuclide \\
5 & 1 & 7.5 & Archival \\
6 & 4 & 12.5 & Archival \\
7 & 1 & 7.5 & Radionuclide \\
& 5 & 6.3 & Radionuclide \\
Rare Number & 6 & 7.3 & Aronuclide \\
INEL \#8 & 1 & 12.5 & Archival \\
INEL \#9 & 3 & 7.5 & Radionuclide \\
INEL \#10 & Filter cloth & NA & Radionuclide \\
INEL \#11 & Rock & NA & Archival \\
INEL \#12 & Soil & 25 & Microbial \\
INEL \#13 & Soil & 25 & Microbial \\
INEL \#14 & Soil & 25 & Microbial \\
INEL \#15 & Soil & 25 & Microbial \\
INEL \#16 & Soil & NA & Microbial \\
INEL \#17 & Waste form scraping & NA & Radionuclide \\
\hline
\end{tabular}


The analyses show that Cs-137 is present throughout the depth of the cores. Three peaks are seen in the cesium content of the ceriter core: one at $24 \mathrm{~cm}$, a large peak at $39 \mathrm{~cm}$, and a smaller peak at $64 \mathrm{~cm}$. Two peaks are seen in the cesium content of the side core: one at $29 \mathrm{~cm}$ and another at $3 \mathrm{~cm}$. These peaks may be indicative of some sort of periodic movement of the cesium, but further study is necessary before the cause of this movement can be determined.

During the sectioning of the center core, it was noticed that there was a fine plant root present throughout the depth of the core. The root material was extracted from each segment and counted (Table IV). Cesium-137 activity is associated with the root, and the peaks in the root data occur at the same depths as do the peaks in the sand activity. It can be seen that there are higher concentrations of Cs-137 associated with the root than with the sand. Sand from the deepest three segments was analyzed: each whole segment was analyzed, and two subsamples of

each segment were analyzed. Segment 2 (Table IV) has a fairly wide range of activities between the whole segment and the two subsamples, suggesting that the activity in the sand is not evenly distributed. This could be a result of the root being involved in the transport process.

Strontium-90 analysis results show that there is significant strontium throughout the entire depth of the center core (Table IV). Peaks occur in the distribution at the same depths as for cesium in both the sand and roots. This suggests that the same mechanism may be involved for transporting strontium upward as cesium. Strontium and cesium behave very differently chemically, but if the process of migration is more physical than chemical, the ratio of Cs-137 to $\mathrm{Sr}-90$ should be similar at all depths. Table IV includes this ratio versus depth. It can be seen that the ratios are similar for most of the segments of the center core, indicating that the upward transport is possibly related to a physical phenomenon such as transpiration enhanced by the presence of the root. The fact that the sand has a very low cation-exchange capacity is probably the reason that the physical aspect of migration is so evident.

Upward migration of radionuclides is being examined in the waste form, and the soil sampling plan is now under way. The results of that work is expected to provide more information on this subject. Those data should be available for the final paper.

\section{Partition Coefficients of Lysimeter Fill Material}

Partition coefficients for Cs-137 and Sr-90 were measured in the laboratory for the lysimeter fill materials. Batch methods were used (9). Table $V$ lists the $K_{d}$ values for ANL-E and ORNL soils and silica sands. While the sorption isotherms reported were not linear over the test range for the low concentrations of radionuclides observed in the lysimeter leachates, the coefficients may be treated as linear. 
Table IV. Cesium and strontium analyses for sand segments from the center (core c) and side (core s) and root fragments from the center of ORNL lysimeter 5 .

\begin{tabular}{|c|c|c|c|c|c|c|c|c|c|c|c|c|c|c|}
\hline \multirow{2}{*}{\multicolumn{2}{|c|}{ Segment \# }} & \multirow[b]{3}{*}{$\begin{array}{c}\text { Depth } \\
(\mathrm{cm})\end{array}$} & \multicolumn{10}{|c|}{ Sand } & \multicolumn{2}{|c|}{ Plant Root } \\
\hline & & & \multicolumn{2}{|c|}{\begin{tabular}{|c|} 
Segment Dry Weight \\
$(\mathrm{g})$
\end{tabular}} & \multicolumn{2}{|c|}{$\begin{array}{l}\mathrm{Cs}-137 \\
(\mathrm{pCi} / \mathrm{g}) \\
\end{array}$} & \multicolumn{2}{|c|}{$\begin{array}{l}\mathrm{Cs}-134 \\
(\mathrm{pCi} / \mathrm{g})\end{array}$} & \multirow{2}{*}{$\frac{\begin{array}{c}\mathrm{Sr}-90 \\
(\mathrm{pCi} / \mathrm{g})\end{array}}{\underset{c}{\mathrm{Core}}}$} & \multicolumn{2}{|c|}{$\begin{array}{c}\text { Ratio }^{\mathbf{a}} \\
\text { Cs-137/Cs-134 }\end{array}$} & \multirow{2}{*}{\begin{tabular}{|c|}
$\begin{array}{c}\text { Ratio }^{c} \\
\text { Cs-137/Sr-90 }\end{array}$ \\
$\begin{array}{c}\text { Core } \\
\text { c }\end{array}$ \\
\end{tabular}} & \multirow{2}{*}{$\begin{array}{l}\text { Sample } \\
\text { Weight } \\
\text { (g) }\end{array}$} & \multirow[b]{2}{*}{$\begin{array}{l}\mathrm{Cs}-137 \\
(\mathrm{pCi} / \mathrm{g})\end{array}$} \\
\hline $\begin{array}{c}\text { Core } \\
\mathrm{c}\end{array}$ & $\begin{array}{c}\text { Core } \\
\mathbf{s}\end{array}$ & & $\begin{array}{c}\text { Core } \\
\mathrm{c}\end{array}$ & $\begin{array}{c}\text { Core } \\
\mathbf{s}\end{array}$ & $\begin{array}{c}\text { Core } \\
\text { c }\end{array}$ & $\begin{array}{c}\text { Core } \\
\mathrm{s}\end{array}$ & $\begin{array}{c}\text { Core } \\
\text { c }\end{array}$ & $\begin{array}{c}\text { Core } \\
s\end{array}$ & & $\begin{array}{c}\text { Core } \\
\mathbf{c}\end{array}$ & $\begin{array}{c}\text { Core } \\
s\end{array}$ & & & \\
\hline$-^{c}$ & 1 & $76.5-71.5$ & - & 126.11 & - & 0.26 & - & $N D^{d}$ & - & - & e & \multirow{4}{*}{450} & - & - \\
\hline 1 & 2 & $71.5-66.5$ & 100.68 & 139.80 & 598.1 & 0.20 & 1.5 & ND & 1.5 & 399 & & & 0.0134 & 18,900 \\
\hline 1 & - & $71.5-66.5$ & 17.08 & - & 704.5 & - & 1.6 & - & - & 448 & & & - & - \\
\hline 1 & - & $71.5-66.5$ & 17.16 & - & 660.8 & - & 1.6 & - & - & 425 & & & - & - \\
\hline 2 & 3 & $66.5-61.5$ & 118.92 & 120.32 & $1,303.4$ & 0.22 & 1.8 & ND & 3.5 & 724 & & \multirow[t]{3}{*}{650} & 0.0172 & 20,660 \\
\hline 2 & - & $66.5-61.5$ & 17.48 & - & 2,241 & - & 2.3 & - & - & 969 & & & - & - \\
\hline 2 & - & $66.5-61.5$ & 20.37 & - & 1,550 & - & 1.8 & - & - & 882 & & & - & - \\
\hline 3 & 4 & $61.5-56.5$ & 121.53 & 131.40 & 356.7 & 0.19 & 0.7 & ND & 2.0 & 484 & & \multirow[t]{3}{*}{200} & 0.0301 & 20,480 \\
\hline 3 & - & $61.5-56.5$ & 19 & - & 400.7 & - & 0.8 & - & - & 498 & & & - & - \\
\hline 3 & - & $61.5-56.5$ & 14.85 & - & 376 & - & 0.7 & - & - & 517 & & & - & - \\
\hline 4 & 5 & $56.5-51.5$ & 115.25 & 109.76 & 490.2 & 0.24 & 1.1 & ND & 2.1 & 447 & & 300 & 0.0234 & 22,540 \\
\hline 5 & 6 & $51.5-46.5$ & 117.07 & 115.29 & 403.3 & 0.17 & 0.8 & ND & 2.7 & 492 & & 200 & 0.0216 & 27,520 \\
\hline 6 & 7 & $46.5-41.5$ & 125.28 & 141.24 & 1,594 & 0.19 & 3.2 & ND & 7.6 & 491 & & 300 & 0.0224 & 27,360 \\
\hline 7 & 8 & $41.5-36.5$ & 129.06 & 113.21 & $37,283.1$ & 0.40 & 30.4 & ND & 14.1 & 466 & & 1,000 & 0.0220 & 81,970 \\
\hline 8 & 9 & $36.5-31.5$ & 121.14 & 124.99 & 551.2 & 1.14 & 1.4 & ND & 1.5 & 404 & & 400 & 0.0302 & 13,620 \\
\hline 9 & 10 & $31.5-26.5$ & 116.32 & 117.30 & 866.6 & 38.9 & 2.3 & 0.08 & 3.5 & 376 & 467 & 300 & 0.0196 & 10,150 \\
\hline 10 & 11 & $26.5-21.5$ & 122.86 & 135.38 & $5,484.2$ & 6.1 & 10.9 & ND & 7.6 & 475 & & 750 & 0.0463 & 21,580 \\
\hline 11 & 12 & $21.5-16.5$ & 117.94 & 108.01 & 2032.4 & 2.6 & 4.4 & ND & 16.0 & 458 & & 200 & 0.0256 & 5,990 \\
\hline 12 & 13 & $16.5-11.5$ & 125.78 & 104.74 & 1,513 & 3.5 & 3.6 & ND & 0.5 & 423 & & 3,400 & 0.1049 & 3,850 \\
\hline 13 & 14 & $11.5-6.5$ & 94.99 & 117.22 & 711.7 & 9.0 & 1.8 & 0.02 & 0.2 & 390 & 557 & 4,400 & 0.0615 & 5,940 \\
\hline 14 & 15 & $6.5-0$ & 150.30 & 142.25 & 715.2 & 53.6 & 1.6 & 0.12 & 0.6 & 451 & 462 & 1,200 & 0.3105 & 8,570 \\
\hline $\begin{array}{l}\text { a. Th } \\
\text { b. Th } \\
\text { c. No } \\
\text { d. ND } \\
\text { e. Bla }\end{array}$ & no & $\begin{array}{l}\text { tio of } \mathrm{Cs} \\
\text { ent was } \mathrm{t} \\
\text { letected. } \\
\text { es not ent }\end{array}$ & $\begin{array}{l}137 / \mathrm{Cs}-13 \\
137 / \mathrm{Sr}-90 \\
\text { ken at th }\end{array}$ & $\begin{array}{l}399 . \\
40 . \\
\text { cation. }\end{array}$ & 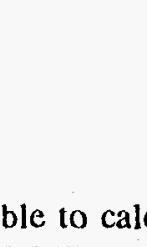 & & & & & & & . & & \\
\hline
\end{tabular}


Table V. Linear $\mathrm{K}_{\mathrm{d}}$ values for cesium and strontium in lysimeter materials.

\begin{tabular}{|c|c|c|}
\hline Material & $\begin{array}{c}\text { Cesium } K_{d} \\
\left(\mathrm{~cm}^{3} / \mathrm{g}\right)\end{array}$ & $\begin{array}{c}\text { Strontium } \mathrm{K}_{\mathrm{d}} \\
\left(\mathrm{cm}^{3} / \mathrm{g}\right)\end{array}$ \\
\hline ANL-E soil & 390 & 81 \\
ORNL soil & 37 & $20-40$ \\
ANL-E sand & 55 & 6.4 \\
ORNL sand & 40 & 6.3 \\
\hline
\end{tabular}

\section{SOURCE TERM MODELING OF LYSIMETER RELEASES}

The Disposal Unit Source Term (DUST) code (10) has been used to model the release of the radionuclides Cs-137 and Sr-90 from the lysimeter waste forms. DUST is a one-dimensional code that accounts for container performance and waste form leaching (including diffusion-controlled release). Transport can be modeled through finite differences or by a multi-cell mixing cascade approach. The finite difference method was used in the simulations reported in this paper because it is more general than the mixing cell approach and permits modeling of dispersive transport. Use of these data in the DUST code was examined in detail in a paper presented at WM '93 (11) and was studied more recently in References (7) and (12).

The releases of Cs-137 and Sr-90 from portland type I-II cement located in the inert, sandfilled lysimeters 5 at ORNL and ANL-E were chosen because releases from other lysimeters were substantially lower; therefore, the data were not yet sufficient to model. At ANL-E, lysimeter 5 contained resin waste from PF-7 solidified in portland type I-II cement; at ORNL, lysimeter 5 contained resin waste from PF-24, which was also solidified in cement (Table I). Diffusion coefficient values measured in laboratory testing of these waste forms were $9.6 \mathrm{E}-10 \mathrm{~cm}^{2} / \mathrm{s}$ for $\mathrm{Sr}-90$ in portland cement and $6.0 \mathrm{E}-10 \mathrm{~cm} / \mathrm{s}$ for $\mathrm{Cs}-137$ in portland cement (13). The Darcy velocities ranged from $2.96 \mathrm{E}-6 \mathrm{~cm} / \mathrm{s}$ at ANL-E to $4.3 \mathrm{E}-6 \mathrm{~cm} / \mathrm{s}$ at ORNL (7). The soil bulk density values were $1.55 \mathrm{~g} / \mathrm{cm}^{3}$ at ANL-E and $1.60 \mathrm{~g} / \mathrm{cm}^{3}$ at ORNL (6). Moisture content values were found in Reference (7). In lysimeter 5 at both sites, the average moisture content was calculated to be $21 \%$. The partition or distribution coefficients were measured for Sr-90 and Cs-137 and are presented in Table V (9). The dispersion coefficients have not been measured; therefore, they were estimated based on data in References (14) and (15) and by fitting the model predictions to the data. The cumulative activity collected in the lysimeter leachate water over the first 10 years of operation of the experiment, which was used to make comparisons to the DUST code predictions, represented cumulative fractional releases of about 0.0018 and 0.00023 of the Sr-90 in lysimeter 5 at ORNL and ANL-E, respectively (Table I). 


\section{ORNL Lysimeter 5 Results}

The "best-fit" parameters for five different waste form release and nuclide transport models are displayed in Table VI. The three waste form release models all limit the total 10-year release from the waste form to about $10^{7} \mathrm{pCi}$, which is two orders of magnitude less than the release predicted on the base case parameters $\left(D_{w f}=9.6 \mathrm{E}-10 \mathrm{~cm}^{2} / \mathrm{s}\right)$. The best-fit diffusion coefficient was four orders of magnitude below the laboratory-measured value. This low release rate is needed to match the data because of the relatively fast transport time that occurs when using the base case $K_{d}$ values. The best-fit transport parameters, $K_{d}=36$, is much larger than the best-fit value found previously based on 8 years of data $\left(K^{\mathrm{d}}=24\right)$. After collecting the additional 2 years of data, it became clear that the previous best fit was too low because the previous model predictions showed a sharp increase in release over the ninth and tenth years.

Figure 4 displays the predicted cumulative release of the four different scenarios and compares them to the measured data. All of them predict the cumulative release over 10 years to within $20 \%$ of the measured value. This is the result of the fitting procedure used to select the appropriate release and transport parameters.

\section{ANL-E Lysimeter 5 Results}

The "best-fit" parameters for ANL-E lysimeter 5 for each of the alternative models are found in Table V. The best-fit parameters differ from those found at ORNL lysimeter 5 . The waste form diffusion coefficient and fractional release rate are lower than at ORNL. The ANL-E waste best-fit coefficient, $1 \mathrm{E}-15 \mathrm{~cm}^{2} / \mathrm{s}$, is a factor of 50 lower than the best-fit value found for the ORNL data and almost six orders of magnitude lower than the laboratory-measured value. The solubility limit is slightly higher than found at ORNL because of the lower water flow rates found at ANL-E.

In Figure 5, the cumulative release based on the solubility limited release model tracks the measured value the best. The uniform and diffusion-controlled waste form release models also follow the trends in the measured data reasonably well. The high $\mathrm{K}_{\mathrm{d}}$ model shows a much different shaped curve than the data or any of the other models.

Table VI. Best-fit parameters for cumulative release from lysimeters 5 at ORNL and ANL-E.

\begin{tabular}{|c|c|c|c|}
\hline Model & Parameter & ORNL & ANL-E \\
\hline $\begin{array}{l}\text { Diffusion-controlled } \\
\text { release }\end{array}$ & $\begin{array}{l}\text { Waste form diffusion } \\
\text { coefficient }\left(\mathrm{cm}^{2} / \mathrm{s}\right)\end{array}$ & $D_{w f}=5 E-14$ & $\mathrm{D}_{\mathrm{wf}}=1 \mathrm{E}-15$ \\
\hline Uniform release & $\begin{array}{l}\text { Uniform fractional } \\
\text { release rate }\left(\mathrm{yr}^{-1}\right)\end{array}$ & $4 \mathrm{E}-4$ & $1.3 \mathrm{E}-4$ \\
\hline Solubility limited & Solubility limit & 1,260 & 1,680 \\
\hline Transport limited & $\begin{array}{l}\mathrm{K}_{\mathrm{d}}\left(\mathrm{cm}^{3} / \mathrm{g}\right) \text {, dispersion } \\
\text { coefficient }(\mathrm{cm})\end{array}$ & $\begin{array}{c}\mathrm{K}_{\mathrm{d}}=36 \\
\text { Disp }=7.5\end{array}$ & $\begin{array}{l}K_{d}=36 \\
\text { Disp }=8\end{array}$ \\
\hline
\end{tabular}




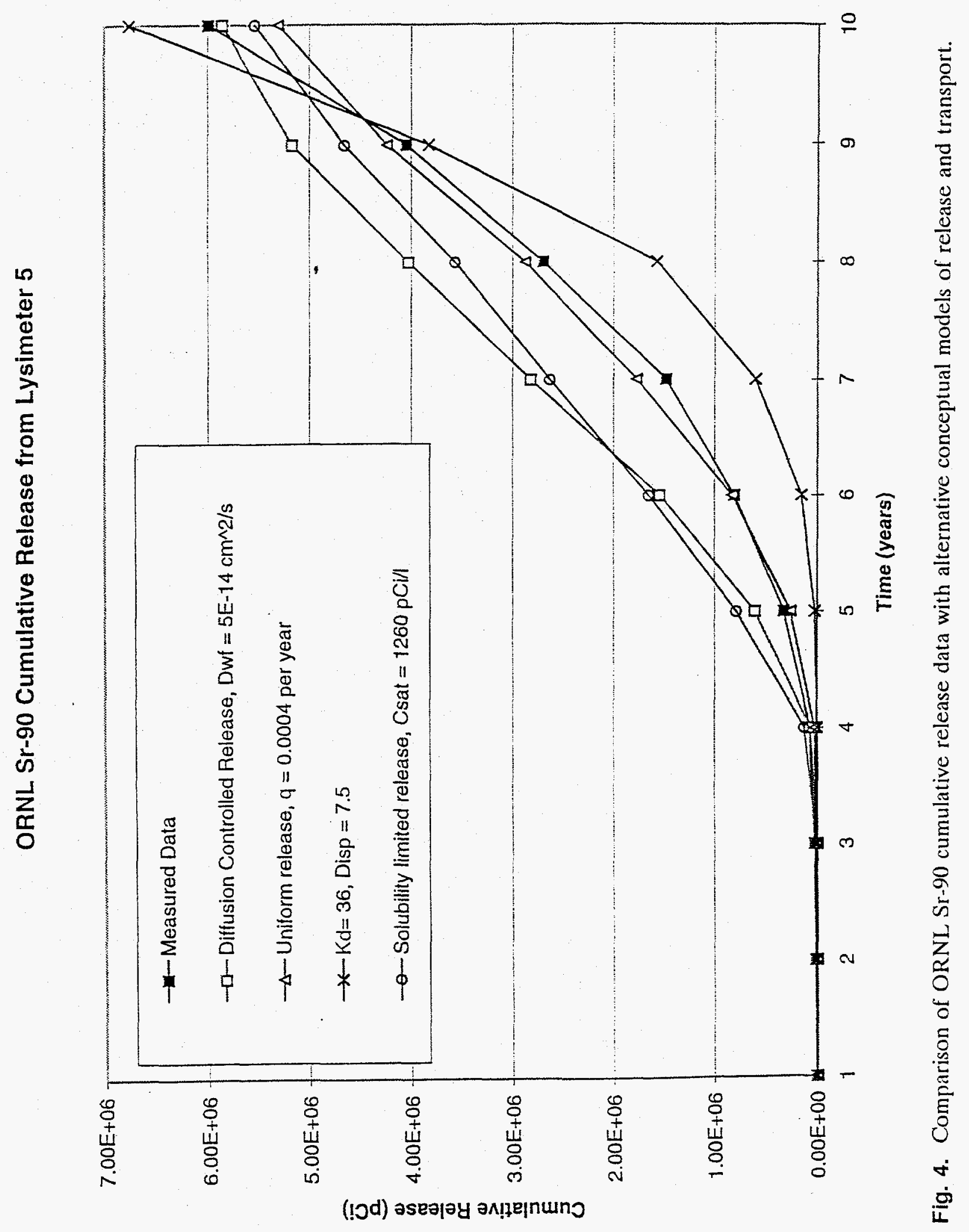




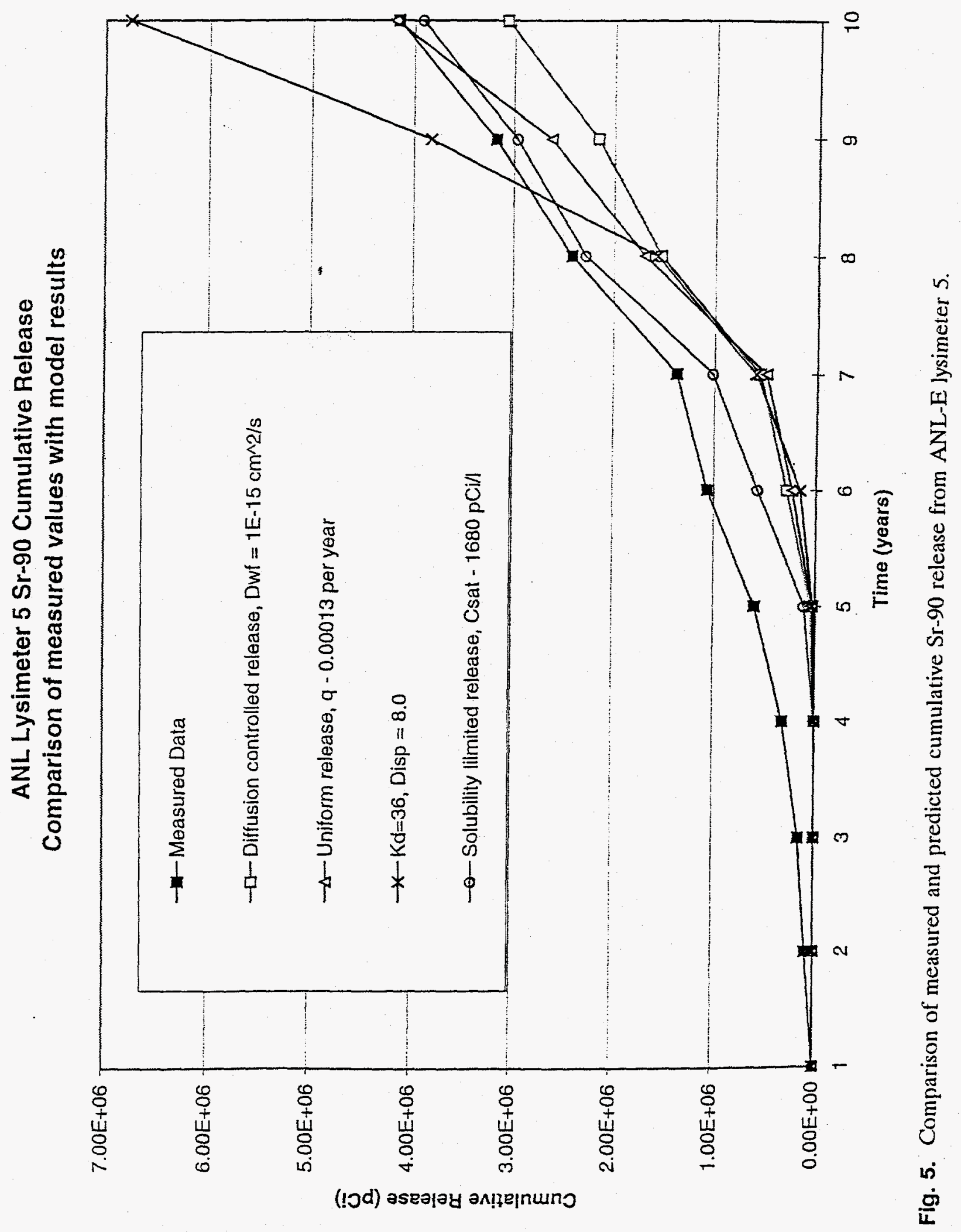




\section{CONCLUSIONS}

The radionuclide that has appeared with most regularity at both sites is Sr-90, although Cs-137 is observed regularly in the leachate of all ORNL lysimeters. A comparison of total Sr-90 found in leachate of the control lysimeters shows that environmental effects have resulted in a much higher release at ORNL. The data indicate that portland cement and VES waste forms have comparable releases of $\mathrm{Sr}-90$.

Cs-137, Cs-134, and Sr-90 are present throughout the upper $80 \mathrm{~cm}$ of the inert sand in ORNL lysimeter 5 directly above the waste form. The ratio of Cs-137/Cs-134 indicates that the radionuclides are from the buried waste form and not from an outside source and were transported vertically upward by some physical mechanism enhanced by the presence of a plant root.

The waste form and soil sampling is developing important data on radionuclide movement from the waste forms into and through the soil columns. It will help to explain differences in releases from cement and VES waste forms and differences in waste form behavior between sites.

DUST-predicted cumulative release of Sr-90 from ORNL lysimeter 5, which was plotted over the first 10 years of data collection, show a reasonable fit to the field data for $\mathrm{K}_{\mathrm{d}}=24$. The accuracy of the DUST modeling study was limited, however, by the lack of measured soil dispersion coefficients. Waste form and soil coring will provide more detail on waste form releases and release patterns to better model the radionuclide movement in the lysimeters.

Data provided by these lysimeter experiments have been shown to be useful in computing many parameters used as input to performance assessment codes. The utility of this reliable source of data will be enhanced by application of radionuclide movement data from soil sampling to source term models such as DUST.

\section{ACKNOWLEDGMENTS}

This work was supported by the U.S. Nuclear Regulatory Commission, Office of Nuclear Regulatory Research, under U.S. Department of Energy Idaho Operations Office Contract DE-AC07-94ID13223.

\section{REFERENCES}

1. CODE OF FEDERAL REGULATIONS, 10 CFR 61, "Licensing Requirements for Land Disposal of Radioactive Wastes," Office of the Federal Register (1982).

2. U.S. NUCLEAR REGULATORY COMMISSION, "Technical Position on Waste Form," Low-Level Waste Management Branch, Washington, DC (1983).

3. U.S. NUCLEAR REGULATORY COMMISSION, "Technical Position on Waste Form," Revision 1, Low-Level Waste Management Branch, Washington, DC (1991). 
4. R. M. NEILSON and J. W. MCCONNELL, JR., "Solidification of EPICOR-II Resin Waste Forms," GEND-INF-055 (1984).

5. R. M. NEILSON, JR. and J. W. MCCONNELL, JR., "EPICOR-II Resin Waste Form Testing," NUREG/CR-4637, EGG-2457 (1986).

6. R. D. ROGERS, J. W. MCCONNELL, JR., E. C. DAVIS, and M. W. FINDLEY, "Field Testing of Waste Forms Containing EPICOR-II Ion Exchange Resins Using Lysimeter," NUREG/CR-4498 (1986).

7. J. W. MCCONNELL, JR., R. D. ROGERS, J. D. JASTROW, D. S. WICKLIFF, and T. M. SULLIVAN, "Annual Report of the Lysimeter Field Investigations: Low-Level Waste Data Base Development Program for Fiscal Year 1995," NUREG/CR-5229, Vol. 8 (1995).

8. R. D. ROGERS, J. W. MCCÓNNELL, JR., E. C. DAVIS, and J. D. JASTROW, "Annual Report of the TMI-2 EPICOR-II Resin/Liner Investigation: Low-Level Waste Data Base Development Program for Fiscal Year 1988," NUREG/CR-5229, Vol. 1 (1988).

9. M. FUHRMANN, "Partition Coefficients of Geomaterials Used in the Nuclear Regulatory Commission Low-Level Waste Lysimeters," letter report (January 1996).

10. T. M. SULLIVAN, "Disposal Unit Source Term (DUST) Data Input Guide," NUREG/CR-6041, BNL-NUREG-52295 (1993).

11. T. M. SULLIVAN, J. W. McCONNELL, JR., R. D. ROGERS, and I. T. FITZGERAID, "Modeling of Field Lysimeter Release Data Using the Computer Code DUST," Waste Management '93 Proceedings of the Symposia on Waste Management, Tucson, AZ, February 28 to March 4, 1993, Vol. 1, pp. 781-5.

12. T. M. SULLIVAN, "Predictive Modeling of Contaminant Release from the Nuclear Regulatory Commission Low-Level Waste Lysimeters, letter report (June 1996).

13. J. W. MCCONNELL, JR., Information presented at the NRC Workshop on Performance Assessment, Washington, D.C. (June 2-5, 1992).

14. D. ISHERWOOD, "Geoscience Data Base Handbook for Modeling a Nuclear Waste Repository," NUREG/CR-0912, Vol. 1 (1981).

15. R. A. FREEZE AND J. A. CHERRY, "Groundwater," Chapter 9, pp. 430-432, Prentice-Hall, Inc., Englewood Cliffs, NJ (1979). 
